\title{
Cadmium, Lead and Zinc in the Soil-Plant-Alpaca System and Potential Health Risk Assessment Associated with the Intake of Alpaca Meat in Huancavelica, Peru
}

\author{
Edith Orellana Mendoza ${ }^{1 *}$, Lilia Pérez Saenz ${ }^{1}$, María Custodio², \\ Wilfredo Bulege ${ }^{3}$, Luz Yallico ${ }^{4}$, Walter Cuadrado ${ }^{5}$
}

1 Facultad de Ciencias Forestales y del Ambiente, Universidad Nacional del Centro del Perú, Av. Mariscal Castilla № 3909-4089, Huancayo, Perú

2 Facultad de Medicina Humana, Universidad Nacional del Centro del Perú, Av. Mariscal Castilla № 3909-4089, Huancayo, Perú

3 Universidad Continental, Av. San Carlos 1980, Huancayo, Perú

${ }^{4}$ Facultad de Enfermería, Universidad Nacional del Centro del Perú, Av. Mariscal Castilla N 3909-4089, Huancayo, Perú

${ }_{5}^{5}$ Facultad de Ciencias Aplicadas, Universidad Nacional del Centro del Perú, Av. Mariscal Castilla № 3909-4089, Huancayo, Perú

* Corresponding author's e-mail: eporellana@uncp.edu.pe

\begin{abstract}
The consumption of contaminated natural pastures with highly dangerous and toxic heavy metals such as cadmium $(\mathrm{Cd})$ and lead $(\mathrm{Pb})$ by Andean camelids could cause harmful effects on the health of people exposed via consumption of contaminated alpaca meat. The concentration of $\mathrm{Cd}, \mathrm{Pb}$ and $\mathrm{Zn}$ in the soil-plant-alpaca system was determined and the potential health risk associated with the intake of alpaca meat was evaluated. Soil and grass samples were collected in grazing areas of the South American camelid, and in the Municipal Slaughterhouse of Huancavelica, 30 samples of alpaca pectoral muscle were collected. The concentrations of $\mathrm{Cd}$ in the soil, grass and alpaca muscle exceeded the threshold values of national and international standards. The bioaccumulation factor values of the three elements studied was less than $1, \mathrm{Cd}$ was the element with the highest bioavailability and mobility in the soil-plant-alpaca muscle system. The mean concentration of $\mathrm{Cd}$ in muscle was $0.335 \pm 0.088 \mathrm{mg} / \mathrm{kg}$ which exceeded the maximum level allowed by the FAO/WHO and the European Commission, the concentration of $\mathrm{Pb}$ and $\mathrm{Zn}$ did not exceed the regulated limits. No significant differences were detected in accumulation according to sex. The non-carcinogenic hazard index (HI) values for the studied metals indicated that there is no adverse health risk $(\mathrm{HI}<1)$ for children and adults from alpaca meat intake, but they could experience carcinogenic risk from prolonged exposure to $\mathrm{Cd}$, and for exceeding the $1 \times 10^{-4}$ limit threshold. It is recommended to conduct further studies on the accumulation of potentially toxic elements in alpaca tissues in order to determine the possible total risk of heavy metals in consumer's health.
\end{abstract}

Keywords: bioaccumulation factor, heavy metals, alpaca meat, non-carcinogenic risk, carcinogenic risk.

\section{INTRODUCTION}

Contamination and accumulation of heavy metals is a serious problem for the environment and human health worldwide [Hu et al. 2017, Ogbomida et al. 2018] due to its toxicity, dangerousness, persistence and non-biodegradable nature and high potential to enter and accumulate in the food chain [Hu et al. 2017, Abah et al. 2017, Asli et al. 2019, Chen et al. 2015, Islam et al. 2018, Stankovic et al. 2014]. Heavy metals are released into the environment by natural and anthropogenic sources [Lü et al. 2018, Wang et al. 2018] can enter soil, water and air, bioaccumulate 
in food webs, to contaminate the food chain and negatively affect the wildlife and human health [Gall et al. 2015, Ali and Khan 2018, Ali et al. 2019]. Metals such as $\mathrm{Pb}$ and $\mathrm{Cd}$ are highly toxic, their presence in the environment even as traces can cause serious problems in the health of animals and plants [Jadia and Fulekar 2009]. These are toxic to living organisms, excessive amounts of elements such as $\mathrm{Pb}$ and $\mathrm{Cd}$ could be harmful to living cells, and prolonged exposure to the body can lead to illness or death (Shafiuddin Ahmed et al., 2019). Cd can enter the human body through ingestion of contaminated food and cause damage to multiple organs [Darwish et al. 2019].

The environment where free-living animals remain strongly influences the content of heavy metals in their tissues [Bąkowska et al. 2016] and the grazing of animals on contaminated soils is a source of exposure and accumulation of heavy metals in the meat of animals [Sabir et al. 2003]. The intake of forage and water with contaminants causes the accumulation of toxic elements in meat and in organs such as the liver and kidney of animals [Felix et al. 2016] and is the most likely route of human exposure to metals compared to other forms of exposure such as inhalation and dermal contact [Bortey-Sam et al. 2015, Hembrom et al. 2020].

Peru is the first reference in the breeding of alpacas under the free grazing system, concentrating $80 \%$ of the world population [Hinojosa et al. 2019]. It constitutes one of the most important productive activities carried out in the high Andean areas above 3800 masl and is a source of family income under rugged geographical conditions. At the national level the population of alpacas is more than 4 million, the department of Huancavelica concentrates $6 \%$ of the national population after Puno, Cusco and Arequipa with 663 tons of annual meat production [Ministery of Agricultural and Irrigation 2019]. The meat of South American camelids is suitable for human consumption due to its chemical composition and quality, it is characterized by its low level of cholesterol and lipids, and represents a source of protein for the Andean population [Cristofanelli et al. 2004, Mamani-Linares et al. 2014, Pérez et al. 2000]. However, the mining activity that is currently abandoned and inactive in the Huancavelica region is a serious problem for the high Andean ecosystems due to the environmental impact generated by the release of toxic waste, clearings, tailings, dust and acid drainage by the mines: Porvenir, Pampamale, Santa Bárbara, Restaurada, Corazón de Jesús, Potocci, Beatita de Melchorita, among others [Ministry of Energy and Mines 2000]. In this context, it is assumed that the food (natural pastures) that the alpaca ingests in the high Andean areas allows the accumulation of metals in the muscle tissue due to its proximity to contaminated environments and that the alpaca meat is not safe for human consumption.

There are several studies on the accumulation of heavy metals in the muscle of cows, sheep, camels, pigs, buffaloes, goats, deer, corsicans, chickens, fish, and sharks; however, there are very few studies related to the accumulation of toxic elements in the muscle of grazing animals such as the alpaca, which are source of animal protein for humans in general. The objective of the present investigation was to determine the concentration of $\mathrm{Cd}, \mathrm{Pb}$ and $\mathrm{Zn}$ in the soil-plantalpaca system and to assess the potential health risk associated with the intake of alpaca meat in Huancavelica, Peru.

\section{MATERIALS AND METHODS}

\section{Collection of samples}

The alpaca muscle samples were collected from the Municipal Slaughterhouse of Huancavelica, located in the Chuñuranra annex of the district, province and department of Huancavelica (Figure 1) at an altitude of 3780 masl between the geographic coordinates of $12^{\circ} 47^{\prime} 25^{\prime \prime} \mathrm{S}$ and $75^{\circ} 02^{\prime} 14.5^{\prime \prime} \mathrm{W}$. South American camelids (alpaca and llama) is one of the main productive activities in the high Andean areas of the country due to the nutritional characteristics of alpaca meat. Alpaca meat is mainly used for commercialization, barter and self-consumption as fresh or dehydrated meat ("charqui").

In the camelid grazing areas and areas surrounding the municipal slaughterhouse of Huancavelica, samples of soil and grass were collected in order to determine the presence of $\mathrm{Cd}, \mathrm{Pb}$ and $\mathrm{Zn}$ where alpacas freely graze. In September 2019 , in order to obtain representative samples of soil and grass, 5 individual composite samples of soil and grass were collected from 5 different points of the meadow. Soil samples were collected from 0 to $20 \mathrm{~cm}$ deep using a small stainless steel 


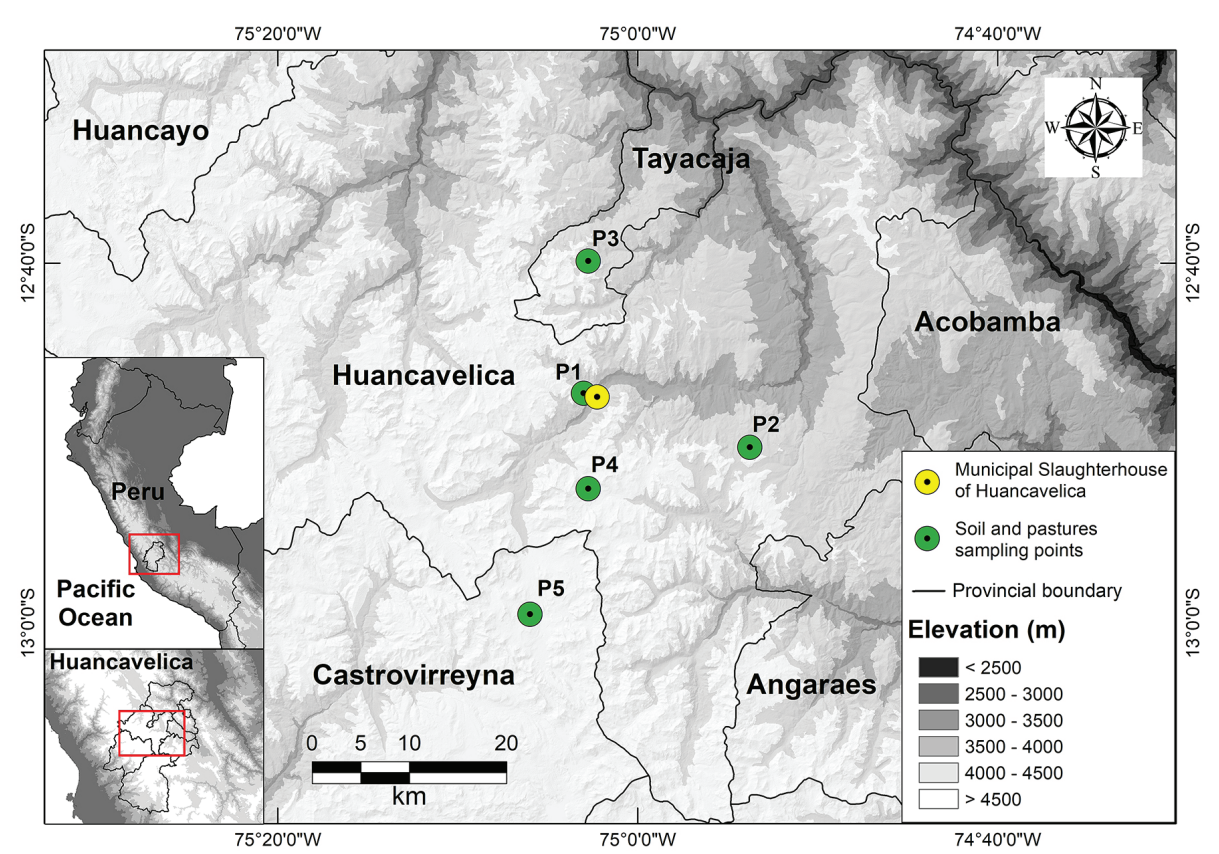

Figure 1. Location map of the Municipal Slaughterhouse of Huancavelica and soil and pasture sampling points

shovel, which were placed in ziploc polyethylene bags. The grass samples were collected from the aerial part using stainless steel scissors from the same points where the soil was collected.

Fresh samples of muscle of alpaca (Vicugna pacos L.) sacrificed were collected in the $\mathrm{Mu}-$ nicipal Slaughterhouse from Huancavelica, 30 raw samples of muscle were collected from the part of the diaphragm [Miranda et al. 2001] of 2 to 3 years old between 15 females and 15 males, each sample weighed approximately $20 \mathrm{~g}$. The samples were packed in transparent and hermetically sealed plastic bags and transported in boxes with ice to the laboratory of the Faculty of Applied Sciences of the National University of the Center of Peru.

\section{Sample preparation and analysis}

The soil samples were dried, pulverized and sieved through a $2 \mathrm{~mm}$ sieve, then $0.5 \mathrm{~g}$ of soil sample was weighed and digested in $10 \mathrm{ml}$ of $\mathrm{HNO}_{3}$ and $3 \mathrm{ml}$ of $\mathrm{HCl}$ for $16 \mathrm{~h}$ at room temperature; then, the digested samples were filtered, diluted with ultrapure water and stored in the refrigerator at $4{ }^{\circ} \mathrm{C}$ prior to analysis. The grass samples were washed with running water, rinsed with distilled water, then proceeded to dehydrate them in the drying oven at $50{ }^{\circ} \mathrm{C}$ for 120 hours, once the samples were dry, they proceeded to grinding using a sprayer, then $1.0 \mathrm{~g}$ of pulverized grass was weighed, these were placed in beakers and digested with $5 \mathrm{ml}$ of $\mathrm{HCl}$ and $5 \mathrm{ml}$ of $\mathrm{HNO}_{3}$, the digested samples were filtered, diluted with ultrapure water and transferred into $20 \mathrm{ml}$ flasks, and stored at $4{ }^{\circ} \mathrm{C}$.

The meat samples were cut into small pieces of 8 to $10 \mathrm{~mm}$, removing the fat and tendons, the samples were homogenized with the help of a domestic mixer. The general digestion phase was performed according to the procedure established by USEPA 3051A [USEPA 2007]. One g of muscle was weighed for each sample and they were placed in beakers, to then proceed to acid digestion with $20 \mathrm{ml}$ of nitric acid $\left(\mathrm{HNO}_{3}\right)$ to cause the decomposition of the muscles, the solutions were brought to the oven at $150{ }^{\circ} \mathrm{C}$ until dry, then allowed to cool, diluted with distilled water, filtered and transferred into $50 \mathrm{ml}$ flasks with ultrapure water. The quantification of the concentration of $\mathrm{Cd}, \mathrm{Pb}$ and $\mathrm{Zn}$ in the selected samples was carried out using the atomic absorption spectrophotometer (VARIAN AA240). Before proceeding with the metal reading, the instrument was calibrated using standard solutions for $\mathrm{Cd}, \mathrm{Pb}$, and $\mathrm{Zn}$ to establish standard calibration curves for each metal.

\section{Bioaccumulation factor}

The bioaccumulation factor (BAF) was used to assess the transfer of $\mathrm{Cd}, \mathrm{Pb}$ and $\mathrm{Zn}$ from soil to plant. It was defined as the ratio of heavy metals concentration in edible parts of plants with the metal concentration in soils. It can be calculated as the equation (1) [Cui et al. 2004]: 


$$
B A F=\frac{\text { Cplant }}{\text { Csoil }}
$$

where: Cplant and Csoil represent $\mathrm{Pb}, \mathrm{Cd}$ and $\mathrm{Zn}$ concentration in plants and soils samples, respectively.

\section{Human health risk assessment}

The human health risk assessment for heavy metals from alpaca meat consumption was calculated based on the methodology proposed by the USEPA [USEPA 1989, 2001]:

\section{Estimated daily intake}

The estimated daily intake (EDI) of $\mathrm{Cd}, \mathrm{Pb}$ and $\mathrm{Zn}$ depends on the concentration of the metal in the alpaca muscle and the amount of consumption of this food. The EDI of heavy metals through the ingestion route was calculated using equation (2) [USEPA 2001, Anandkumar et al. 2020, El Bayomi et al. 2018]:

$$
E D I=\frac{C m \times I R}{B W}
$$

where: $E D I$ is the estimated daily intake in $\mathrm{mg} /$ kg-day,

$\mathrm{Cm}$ is the average concentration of metal in food ( $\mathrm{mg} / \mathrm{kg}$, in fresh weight),

$I R$ is the average daily consumption of alpaca meat in this region $(\mathrm{kg} /$ day);

$B W$ is the average body weight $(\mathrm{kg})$. A questionnaire was applied to 45 people to determine the average daily consumption of alpaca meat of children $(0.078 \pm 0.007 \mathrm{~kg} /$ day $)$ and adults $(0.182 \pm 0.045 \mathrm{~kg} /$ day $)$ and the average body weight of children $(18.8 \pm 0.940 \mathrm{~kg})$ and adults $(64.5 \pm 9.98 \mathrm{~kg})$.

\section{Non-carcinogenic risk}

The non-carcinogenic risk by heavy metals in the health of local inhabitants of Huancavelica from alpaca meat intake was assessed on the basis of the hazard quotient (HQ), which was expressed by equation (3) [USEPA 1989, 2001, Korkmaz et al. 2019]:

$$
H Q=\frac{E F x E D x E D I}{R f D x B W x A T}
$$

where: $E F$ is the exposure frequency (350 days/ year),
$E D$ is the duration of exposure (70 years) and $R f D(\mathrm{mg} / \mathrm{kg}$-day) is the oral reference dose for each contaminant, the $R f D$ values for $\mathrm{Cd}, \mathrm{Pb}$ and $\mathrm{Zn}$ are $0.001,0.0036$ and $0.3 \mathrm{mg} / \mathrm{kg}$-day respectively [Chijioke et al. 2020, USEPA IRIS 2019]. $B W$ is the body weight in $\mathrm{kg}$ and $A T$ is the average time of exposure to non-carcinogenic heavy metals $(E D \times 350$ days). If $H Q$ is less than 1 , there is no probable health risk, if $H Q$ is greater than 1 , the consumption of alpaca meat could mean a possible danger to the health of consumers [Djedjibegovic et al. 2020, Kortei et al. 2020].

To estimate the general non-carcinogenic risk to human health of $\mathrm{Cd}, \mathrm{Pb}$ and $\mathrm{Zn}$, the hazard index (HI) was calculated using equation (4), which consisted of the sum of the hazard quotients of the metals individual [Barath $\mathrm{Ku}$ mar et al. 2019]:

$$
\mathrm{HI}=\text { Total } \mathrm{HQ}=\mathrm{HQ}_{(\mathrm{Pb})}+\mathrm{HQ}_{(\mathrm{Cd})}+\mathrm{HQ} \mathrm{(Zn)}
$$

if $\mathrm{HI}<1$, the probability of adverse health effects is low, the exposure level is lower than the $R f D$, if $\mathrm{HI}>1$, daily exposure is likely to cause adverse effects during a person's life [Oyekunle et al. 2020].

\section{Carcinogenic risk}

The carcinogenic risk (CR) during a lifetime of exposure to $\mathrm{Cd}$ and $\mathrm{Pb}$ was calculated using equation (5) [USEPA 1989, 2001, Korkmaz et al. 2019]:

$$
C R=\frac{E F x E D x E D I x C S F}{B W \times A T}
$$

where: $A T$ is the mean time for carcinogens $(70 \times$ 365 days);

CFS is the oral carcinogenic risk factor for metals, the CFS for $\mathrm{Cd}$ and $\mathrm{Pb}$ is $15 \mathrm{mg} / \mathrm{kg}$-day and $0.0085 \mathrm{mg} / \mathrm{kg}$-day respectively [Miclean et al. 2019, Storelli et al. 2020, L. Zhang et al. 2015]. $E F, E D$, $E D I$ and $B W$ were defined in equations (1) and (2). The acceptable range of the $C R$ value is between $1 \times 10^{-6}$ to $1 \times 10^{-4}$, if the threshold value of $C R$ is below $1 \times 10^{-6}$ it is accepted that there are no significant risks to human health, and if the $C R$ threshold value exceeds $1 \times 10^{-4}$ indicates a potential lifetime carcinogenic risk [USEPA 2001]. $\mathrm{Cd}$ and $\mathrm{Pb}$ were treated as potentially 
carcinogenic contaminants according to the classification order defined by the International Agency for Research on Cancer [IARC 2012].

The total carcinogenic risk (TCR) to human health of $\mathrm{Cd}$ and $\mathrm{Pb}$ was calculated using equation (6):

$$
\mathrm{TCR}=\text { Total } \mathrm{CR}=\mathrm{CR}_{(\mathrm{Pb})}+\mathrm{CR}_{(\mathrm{Cd})}
$$

\section{Statistical analysis}

The normality and equality of the data variations were analyzed using the Shapiro-Wilk and Levene tests, respectively. The accumulation data of $\mathrm{Cd}$ and $\mathrm{Zn}$ in the alpaca muscle were analyzed using the $t$ test for independent samples $(p<0.05)$ to compare the differences in accumulation according to sex. The data on the $\mathrm{Pb}$ content in the alpaca muscle did not present a normal distribution and were analyzed using the non-parametric test of U Man of Whitney.

\section{RESULTS AND DISCUSSION}

\section{Concentration of $\mathrm{Cd}, \mathrm{Pb}$ and $\mathrm{Zn}$ in soils and grasses}

The results of the concentration of $\mathrm{Cd}, \mathrm{Pb}$ and $\mathrm{Zn}$ in the soil and grass in the grazing areas of the South American camelid (alpaca) are presented in the Table 1. The average concentration of $\mathrm{Cd}$ in the soil was $2.78 \mathrm{mg} / \mathrm{kg}$, and these concentrations ranged from 1.32 to $3.87 \mathrm{mg} / \mathrm{kg}$. The mean concentration of $\mathrm{Pb}$ in the soil was $22.12 \mathrm{mg} / \mathrm{kg}$ and $\mathrm{Zn} 95.94 \mathrm{mg} / \mathrm{kg}$ below the regulated limits. The average concentration of $\mathrm{Cd}$ in the soil was higher than the environmental quality standards for soil of the national regulation [Ministery of the Environment 2017] and international [CCME 2007], the concentrations of $\mathrm{Pb}$ and $\mathrm{Zn}$ in the soil did not exceed the regulated limits. The high concentrations of $\mathrm{Cd}$ in the topsoil could be attributed to the presence of abandoned mines surrounding the alpaca grazing area.

Table 1. Concentration of $\mathrm{Cd}, \mathrm{Pb}$ and $\mathrm{Zn}$ in soil and grass and bioaccumulation factor in the camelid grazing areas from Huancavelica, Peru

\begin{tabular}{|c|c|c|c|c|}
\hline Samples & Sampling points & $\mathrm{Cd}$ & $\mathrm{Pb}$ & $\mathrm{Zn}$ \\
\hline \multirow{6}{*}{ Soil (mg/kg) } & P1 & 1.790 & 21.580 & 106.050 \\
\hline & P2 & 1.320 & 13.890 & 87.480 \\
\hline & P3 & 3.160 & 17.370 & 98.890 \\
\hline & P4 & 3.870 & 36.540 & 77.980 \\
\hline & P5 & 3.760 & 21.200 & 109.280 \\
\hline & Mean & 2.78 & 22.116 & 95.936 \\
\hline \multirow{6}{*}{ Grass (mg/kg) } & P1 & 0.887 & 1.203 & 56.673 \\
\hline & P2 & 1.863 & 2.463 & 11.135 \\
\hline & P3 & 1.956 & 0.557 & 65.063 \\
\hline & P4 & 1.760 & 2.980 & 72.530 \\
\hline & P5 & 0.817 & 2.876 & 64.327 \\
\hline & Mean & 1.456 & 2.016 & 53.946 \\
\hline \multirow{6}{*}{ BAF } & P1 & 0.495 & 0.056 & 0.534 \\
\hline & P2 & 1.411 & 0.177 & 0.127 \\
\hline & P3 & 0.619 & 0.032 & 0.658 \\
\hline & P4 & 0.455 & 0.082 & 0.930 \\
\hline & P5 & 0.217 & 0.136 & 0.589 \\
\hline & Mean & 0.640 & 0.096 & 0.568 \\
\hline \multirow{2}{*}{ Soil Standards } & Canadian CEQG & 1.4 & 70 & 200 \\
\hline & Peruvian SQE & 1.4 & 70 & - \\
\hline \multirow{2}{*}{ Grasses Standards } & EC & 1 & 30 & - \\
\hline & NAS & 1 & 250 & 300 \\
\hline
\end{tabular}

Canadian Environmental Quality Guidelines-CEQG (CCME, 2007); Standard Quality Environment-SQE (Ministery of the Environment, 2017); European Union Standard-EC (European Commission (EC), 2006b); National Academy of Sciences-NAS (National Academy of Sciences, 2005) 
Canadian Environmental Quality GuidelinesCEQG (CCME, 2007); Standard Quality Environment-SQE (Ministery of the Environment, 2017); European Union Standard-EC (European Commission (EC), 2006b); National Academy of Sciences-NAS (National Academy of Sciences, 2005).

The content of $\mathrm{Cd}, \mathrm{Pb}$ and $\mathrm{Zn}$ in the natural pastures samples collected from the same sites from which the soil samples were taken ranged from 0.59 to $2.90 \mathrm{mg} / \mathrm{kg}, 0.47$ to $5.03 \mathrm{mg} / \mathrm{kg}$ and 8.54 to $89.20 \mathrm{mg} / \mathrm{kg}$ respectively. The average content of $\mathrm{Cd}$ in the grass exceeded that established in international standards. More of than $70 \%$ of the samples studied exceeded the threshold limit for Cd in forages $(1 \mathrm{mg} / \mathrm{kg})$ according to European regulation [European Commission 2006b] which could indicate that alpacas would be exposed to this element by daily intake of pastures with $\mathrm{Cd}$ residues. The soil $\mathrm{Cd}$ can be easily absorbed by plants and accumulate in animal food through the food chain [Hashemi 2018, $\mathrm{Yu}$ et al. 2017]. The concentrations of $\mathrm{Pb}$ and $\mathrm{Zn}$ in the pasture did not exceed the limit regulated by the European Commission $(30 \mathrm{mg} / \mathrm{kg}$ ) and the tolerable limit $(150 \mathrm{mg} / \mathrm{d})$ regulated by the National Academy of Sciences [National Academy of Sciences 2005, Smith et al. 2009]. The results obtained could suggest that the soil is exposed to a large amount of pollutants such as heavy metals, and these could be transferred to plants and affect food security [S. Khan et al. 2008, Xiao et al. 2019].

\section{Translocation from soil to plants}

The bioaccumulation factor measures the ability to move metals from the soil to the plants. The BAF values of $\mathrm{Cd}, \mathrm{Pb}$ and $\mathrm{Zn}$ are presented in the Table 1. The BAF for the studied grass samples decreased in the following order $\mathrm{Cd}>$ $\mathrm{Zn}>\mathrm{Pb}$, higher $\mathrm{BAF}$ values were observed in $\mathrm{Cd}$ and $\mathrm{Zn}$ because these elements are absorbed with extreme ease [Kabata-Pendias 2011]. The BAF values of the three elements studied in the natural pastures were less than 1 , these values indicate that the absorption was low to medium intensity. The presence of these chemical substances in the tissues of the pastures would pose a danger to the animal that consumes it daily through free grazing. The roots, shoots and meristems of plants absorb most of $\mathrm{Cd}$ and $\mathrm{Zn}$ [Wilkinson et al. 2003] due to its greater bioavailability and mobility of these two elements [Kabata-Pendias 2011]. In general, the $\mathrm{Cd}, \mathrm{Pb}$ and $\mathrm{Zn}$ contents in the soil and pastures presented high variability, possibly as a consequence of the presence of sources of contamination related to mining activities, especially the passives of abandoned mining tailings that favor the dispersion of dust with metal content in the area surrounding the alpaca grazing area.

\section{Concentration of $\mathrm{Cd}, \mathrm{Pb}$ and $\mathrm{Zn}$ in alpaca muscle according to sex}

The presence of $\mathrm{Cd}, \mathrm{Pb}$ and $\mathrm{Zn}$ was detected in the alpaca muscle, which suggests a possible contamination of the muscle tissue with these chemical elements. The average accumulation of these metals followed the following decreasing order $\mathrm{Zn}>\mathrm{Cd}>\mathrm{Pb}$, with 28.288, 0.335 and $0.0048 \mathrm{mg} / \mathrm{kg}$ respectively (Table 2 and Figure 2). The mean content of $\mathrm{Cd}$ in the muscle of male and female alpaca was 0.334 and $0.336 \mathrm{mg} / \mathrm{kg}$, $\mathrm{Pb} 0.0048$ and $0.0049 \mathrm{mg} / \mathrm{kg}$ and $\mathrm{Zn} 29.610$ and $26.966 \mathrm{mg} / \mathrm{kg}$ respectively.

The Cd content in all the muscle samples studied exceeded the safety threshold allowed by the European Commission [European Commission 2006a]. These $\mathrm{Cd}$ accumulation values found in alpaca muscle could be an important indicator of the level of contamination of the place where the cattle are raised [Sobhanardakani 2018]. The presence of $\mathrm{Cd}$ in the soil and grass above the regulated limits in the camelid grazing area would corroborate this statement. $\mathrm{Cd}$ is an environmental pollutant that plants easily absorb from the soil and is indirectly transferred to animals through pasture intake [Khan et al. 2018], on the other hand, these heavy metals can be found in the air, water, soil, and especially in pastures near industrial areas [Baydan et al. 2017]. No significant differences were observed in the accumulation of $\mathrm{Cd}, \mathrm{Pb}$ and $\mathrm{Zn}$ in muscle tissue according to sex $(p>0.05)$ coinciding with what was reported by Hermoso de Mendoza et al. [2011]. The average content of $\mathrm{Pb}$ in the alpaca muscle was below the limits regulated by the European Commission and the Codex Alimentarius [FAO/WHO 2015]. There is no permissible regulation for $\mathrm{Zn}$ in meat and the regulation for fish was assumed. $\mathrm{Zn}$ is an essential metal for animals, its concentration in muscle would not represent a danger to the health of consumers, but in high concentrations it can be toxic [ATSDR 2005]. 
Table 2. Concentration of $\mathrm{Cd}, \mathrm{Pb}$ and $\mathrm{Zn}(\mathrm{mg} / \mathrm{kg})$ in muscle of alpaca according sex in Huancavelica, Peru

\begin{tabular}{|l|c|c|c|c|}
\hline \multirow{4}{*}{ Sex } & Descriptive statistics & $\mathrm{Cd}$ & $\mathrm{Pb}$ & $\mathrm{Zn}$ \\
\hline \multirow{4}{*}{ Male } & Mean \pm SD & $0.334 \pm 0.099$ & $0.0048 \pm 0.0029$ & $29.610 \pm 10.229$ \\
\cline { 2 - 5 } & Median & 0.354 & 0.0045 & 26.230 \\
\cline { 2 - 5 } & Min-Max & $0.182-0.502$ & $0.0013-0.0094$ & $17.250-49.920$ \\
\cline { 2 - 5 } Female & Mean \pm SD & $0.336 \pm 0.079$ & $0.0049 \pm 0.0025$ & $26.966 \pm 9.498$ \\
\cline { 2 - 5 } & Median & 0.329 & 0.0043 & 25.830 \\
\hline \multirow{3}{*}{ Specification } & Range & $0.214-0.496$ & $0.0018-0.0101$ & $14.970-46.580$ \\
\hline \multirow{3}{*}{ Meat Standards } & General mean & $0.335 \pm 0.088$ & $0.0048 \pm 0.0027$ & $28.288 \pm 9.791$ \\
\cline { 2 - 5 } & EuOP/WHO & 0.05 & 0.1 & - \\
\cline { 2 - 5 } & Fun Commission & 0.2 & 0.1 & 40 \\
\hline
\end{tabular}

FAO/WHO (FAO/WHO, 2015); European Commission (European Commission (EC), 2006a); FAO (FAO, 1983)

These results of $\mathrm{Cd}$ content in alpaca muscle were higher than that reported by Huanqui Pérez [2018] in Puno, but similar in the content of Pb. Likewise, the results found were compared with studies of heavy metals found in sheep, cow, buffalo, and camel meat, these were similar to those reported by Khalafalla et al. [2015] in Egypt with $\mathrm{Cd}$ concentrations that ranged from 0.2 to $0.9 \mathrm{ppm}$ respectively. In sheep muscle they reported lower contents for $\mathrm{Cd}$, but similar for $\mathrm{Pb}$ and $\mathrm{Zn}$ [MacLachlan et al. 2016]; in bovine meat they reported higher values for $\mathrm{Pb}$, and lower values for $\mathrm{Cd}$ and $\mathrm{Zn}$ (Hashemi, 2018); in camel muscle they reported similar values for $\mathrm{Pb}$ and $\mathrm{Zn}$ and lower for $\mathrm{Cd}$, similarly they did not observe significant differences in the accumulation of these elements between males and females [Asli et al. 2019]; in deer muscle they reported $\mathrm{Pb}$ contents higher than that found in this study [Lehel et al. 2015]. In goat muscle they reported lower contents for $\mathrm{Cd}$, higher for $\mathrm{Pb}$ and similar for $\mathrm{Zn}$ [Ogbomida et al. 2018]. In Ukraine, in wild boar, roe deer and hare muscle they found $\mathrm{Cd}$ and $\mathrm{Pb}$ values above the permissible limits [Pilarczyk et al. 2020]. In China, in different food groups reported higher average concentration of $\mathrm{Cd}$ in animal meat with $0.303 \mathrm{mg} / \mathrm{kg}$ [Yu et al. 2017]. The presence of $\mathrm{Cd}, \mathrm{Pb}$ and $\mathrm{Zn}$ in the alpaca muscle would be attributed to the daily and direct intake of pastures with contents of these elements in the plant tissue through the free grazing of camelids in the high Andean areas, which would favor the accumulation of these heavy metals in the animal's body.

\section{Estimated daily intake of $\mathrm{Cd}, \mathrm{Pb}$ and $\mathrm{Zn}$ associated with the alpaca meat intake}

The estimated daily intake of $\mathrm{Cd}, \mathrm{Pb}$ and $\mathrm{Zn}$ are presented in Table 3. The trend of daily intake followed the following decreasing order $\mathrm{Zn}>\mathrm{Cd}>\mathrm{Pb}$ for both children and adults, with a
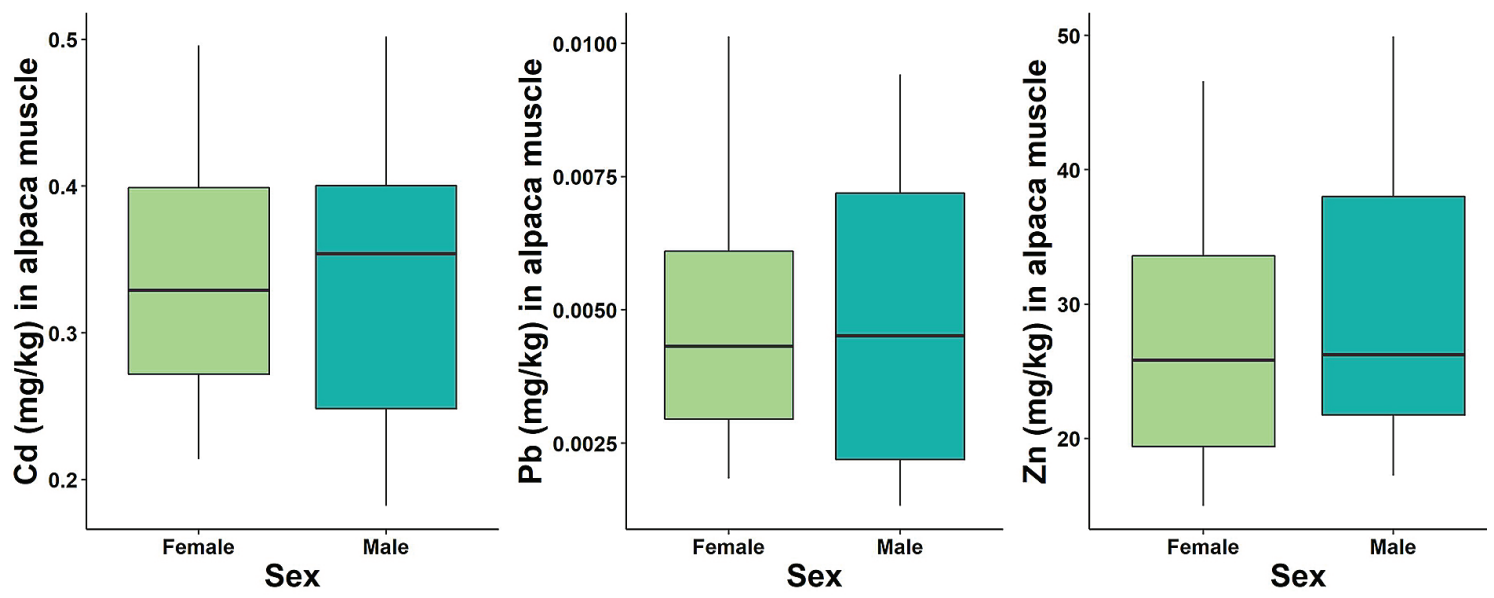

Figure 2. Accumulation of $\mathrm{Cd}, \mathrm{Pb}$ y $\mathrm{Zn}$ in alpaca muscle according sex 
Table 3. Estimated daily intake (mg/kg-day), Hazard Quotient, Hazard Index and Total Cancer Risk of Cd, Pb and $\mathrm{Zn}$ from consumption of alpaca meat in Huancavelica, Peru

\begin{tabular}{|c|c|c|c|c|c|c|c|c|}
\hline \multirow{2}{*}{$\begin{array}{l}\text { Heavy } \\
\text { metal }\end{array}$} & \multirow{2}{*}{$\begin{array}{l}\text { Concentration } \\
\text { in meat } \\
(\mathrm{mg} / \mathrm{kg})\end{array}$} & \multirow{2}{*}{$\begin{array}{c}\text { RfD } \\
\text { (mg/kg-day) }\end{array}$} & \multicolumn{2}{|c|}{$\begin{array}{c}\text { EDI } \\
\text { (mg/kg-day) }\end{array}$} & \multicolumn{2}{|c|}{$\begin{array}{c}\text { Hazard Quotient } \\
(\mathrm{HQ})\end{array}$} & \multicolumn{2}{|c|}{$\begin{array}{l}\text { Cancer Risk } \\
(\mathrm{CR})\end{array}$} \\
\hline & & & Children & Adult & Children & Adult & Children & Adult \\
\hline $\mathrm{Cd}$ & 0.335 & 0.001 & 2.89E-04 & 1.97E-04 & 2.89E-01 & $1.97 \mathrm{E}-01$ & 4.34E-03 & 2.95E-03 \\
\hline $\mathrm{Pb}$ & 0.0048 & 0.0036 & 4.14E-06 & 2.82E-06 & 1.15E-03 & 7.83E-04 & $3.52 \mathrm{E}-08$ & 2.39E-08 \\
\hline $\mathrm{Zn}$ & 28.288 & 0.3 & 2.44E-02 & $1.66 \mathrm{E}-02$ & 8.14E-02 & 5.53E-02 & - & - \\
\hline \multicolumn{5}{|c|}{ Hazard Index (HI) } & 3.72E-01 & $2.53 \mathrm{E}-01$ & & \\
\hline \multicolumn{7}{|c|}{ Total Cancer Risk (TCR) } & 4.34E-03 & 2.95E-03 \\
\hline
\end{tabular}

maximum exposure of $2.44 \times 10^{-2} \mathrm{mg} / \mathrm{kg}$-day of $\mathrm{Zn}$ in children and a minimum of $2.82 \times 10^{-6} \mathrm{mg} /$ kg-day of $\mathrm{Pb}$ in adults.

Alpaca meat is one of the sources rich in protein and low in cholesterol [FAO 2005], the fresh meat contains $21.8 \%$ protein, $3.7 \%$ fat, $1.4 \%$ ash and $70.80 \%$ moisture; while the dehydrated meat contains $57.2 \%$ protein, $7.5 \%$ fat, $3.3 \%$ ash and $28.8 \%$ moisture [DESCOSUR 2017], so its consumption is recommended. Muscle tissue is the most worrying because it is the most edible part of the camelid and commonly consumed by humans. However, the accumulation of heavy metals in the muscle tissue of the alpaca can be transferred to humans through the consumption of its meat products, and the toxicity of the metals would depend on the rate of daily intake. The daily intakes of $\mathrm{Cd}$, $\mathrm{Pb}$ and $\mathrm{Zn}$ were higher in children than in adults, results consistent with that reported by Korkmaz et al. [2019], Pilarczyk et al. [2020] and Zeinali [2019]. FAO/WHO recommends the daily intake of these harmful substances and trace elements that ensure a healthy diet, and prevent toxic effects beyond the permitted limits. The values of the estimated daily intake were below the provisional tolerable daily intakes (PTDI) $\left(8.3 \times 10^{-4}\right.$ $\mathrm{mg} / \mathrm{kg}$-day of $\mathrm{Cd}, 3.6 \times 10^{-3} \mathrm{mg} / \mathrm{kg}$-day of $\mathrm{Pb}$ and $1.0 \mathrm{mg} / \mathrm{kg}$-day of $\mathrm{Zn}$ ) established by $\mathrm{FAO} / \mathrm{WHO}$ [FAO/WHO 1982, 2011] being within the safe level and showing a low level of exposure for consumers of alpaca meat. However, frequent intake of food of animal origin contaminated with heavy metals could increase the level of accumulation in humans [Ogbomida et al. 2018]. $\mathrm{Cd}$ and $\mathrm{Pb}$ are very toxic elements even at the trace level that can cause various diseases, mainly in children because they are more susceptible to the effects of these metals [ATSDR 2020]. On the other hand, zinc is an essential element for the growth and development of children, prolonged exposures to high levels of $\mathrm{Zn}$ can result in a decrease in the absorption of copper in the diet and a decrease in iron stores [ATSDR 2005, Uauy et al. 1998].

\section{Non carcinogenic and carcinogenic risk}

The hazard quotient of $\mathrm{Cd}, \mathrm{Pb}$ and $\mathrm{Zn}$ for children and adults are shown in Table 3 . The estimated $\mathrm{HQ}$ values for $\mathrm{Cd}, \mathrm{Pb}$ and $\mathrm{Zn}$ for children and adults decreased in the following order $\mathrm{Cd}>\mathrm{Zn}>\mathrm{Pb}$ with $2.89 \times 10^{-1}, 8.14 \times 10^{-2}$ and $1.15 \times 10^{-3}$ in children and $1.97 \times 10^{-1}, 5.53 \times 10^{-2}$ and $7.83 \times 10^{-4}$ in adults respectively, and these values were below 1 . The calculated non-cancer risk index (HI) was less than 1 for children and adults. From the cancer risk assessment (CR) by exposure to $\mathrm{Cd}$ and $\mathrm{Pb}$, the $\mathrm{CR}$ values for $\mathrm{Pb}$ were lower than the $\mathrm{CR}$ values for $\mathrm{Cd}$ and the limit threshold value $\left(1 \times 10^{-6}\right)$.

The hazard ratios of $\mathrm{Cd}, \mathrm{Pb}$ and $\mathrm{Zn}$ for children and adults were less than 1 , which could indicate that there is no potential risk to the health of consumers of alpaca meat. The non-carcinogenic risk index was below 1 for children and adults, which could suggest that there is a low probability of experiencing non-carcinogenic risk to human health. $\mathrm{Cd}$ and $\mathrm{Zn}$ were the elements that showed the greatest contribution to HI, the HI values were approximately 1.5 times higher in children than in adults, results consistent with that reported by Sam Bortey-Sam et al. [2015], [Shafiuddin Ahmed et al. 2019] and [Zeinali 2019]. Children are more susceptible to the absorption of toxic metals compared to adults, they are susceptible to deficiencies in respiratory function, cardiovascular disease, deficits in neurological development, bone damage and reproductive problems [Zhang et al. 2019]. Therefore, it is important to pay attention to the daily intake of other toxic elements through the consumption of meat foods, giblets, fruits, vegetables, and water intake by local residents and to evaluate the 
potential of total risk in the health of the inhabitants and in the environment.

The carcinogenic risk for $\mathrm{Pb}$ was within acceptable values for children and adults, which could indicate that there is no potential risk of cancer for life from intake of alpaca meat with $\mathrm{Pb}$ content. The carcinogenic risk of $\mathrm{Cd}$ and $\mathrm{Pb}$ was higher in children than in adults. Regarding $\mathrm{Cd}$, there was greater concern, because TCR levels exceeded the established threshold limit $1 \times 10^{-4}$ [USEPA 2001], therefore, so it might be suggested that there is a lifetime carcinogenic risk for $\mathrm{Cd}$ as this element is considered a group 1 carcinogen and the intake of alpaca meat would not be safe. Young individuals are more vulnerable to the accumulation of $\mathrm{Cd}$, due to irreversible alterations in the central nervous system [Kicińska et al. 2019]. On the other hand, prolonged exposure to $\mathrm{Cd}$ levels causes kidney dysfunction, deficiencies in Ca metabolism causing an increased risk of osteoporosis, $\mathrm{Cd}$ accumulates in the human body throughout life and has a half-life of 10 to 33 years [ATSDR 2012, Kicińska et al. 2019].

\section{CONCLUSIONS}

The concentrations of $\mathrm{Cd}, \mathrm{Pb}$ and $\mathrm{Zn}$ in the soil-plant-alpaca system showed great variability. The concentrations of $\mathrm{Cd}$ in the soil, grass and alpaca muscle exceeded the threshold values of national and international standards, but the concentrations of $\mathrm{Pb}$ and $\mathrm{Zn}$ were within safe limits. The bioaccumulation factor (BAF) value of the three elements studied was less than $1, \mathrm{Cd}$ was the element with the highest bioavailability and mobility from soil to plant. The estimated daily intake was below the tolerable provisional daily intakes (PTDI). The non-carcinogenic risk values (HI) were less than 1 , which would indicate that there is no non-carcinogenic adverse effect for the health of local residents, but they could experience a lifetime carcinogenic risk (CR) from exceeding the limit threshold regulated by USEPA $\left(1 \times 10^{-4}\right)$ for $\mathrm{Cd}$. The consumption of alpaca meat with high levels of $\mathrm{Cd}$ would be a cause of concern for the health of the children and adults from Huancavelica as a highly toxic element. It is recommended to conduct further studies on the accumulation of potentially toxic elements in alpaca tissues in order to determine the possible total risk of heavy metals in consumer's health.

\section{Acknowledgement}

The authors thank the managers of the Municipal Slaughterhouse of Huancavelica for the authorization for the collection of samples.

\section{REFERENCES}

1. Abah J., Mashebe P., Onjefu SA. 2017. Assessment of heavy metals pollution status of the pasture grass around Katima Mulilo Municipal Solid Wastes Dumpsite, Namibia. International Journal of Environmental Science and Development, 8(5), 372377. https://doi.org/10.18178/ijesd.2017.8.5.980

2. Ali H., Khan E. 2018. Trophic transfer, bioaccumulation and biomagnification of non-essential hazardous heavy metals and metalloids in food chains/ webs - concepts and implications for wildlife and human health. Human and Ecological Risk Assessment, 25(6), 1353-1376. https://doi.org/10.1080/1 0807039.2018.1469398

3. Ali H., Khan E., Ilahi I. 2019. Environmental chemistry and ecotoxicology of hazardous heavy metals: Environmental persistence, toxicity, and bioaccumulation. Journal of Chemistry, 2019, 1-14. https:// doi.org/10.1155/2019/6730305

4. Anandkumar A., Li J., Prabakaran K., Xi Jia Z., Leng Z., Nagarajan R., Du D. 2020. Accumulation of toxic elements in an invasive crayfish species (Procambarus clarkii) and its health risk assessment to humans. Journal of Food Composition and Analysis, 88, 103449. https://doi.org/10.1016/j. jfca.2020.103449

5. Asli M., Azizzadeh M., Moghaddamjafari A., Mohsenzadeh M. 2019. Copper, iron, manganese, zinc, cobalt, arsenic, cadmium, chrome, and lead concentrations in liver and muscle in iranian camel (Camelus dromedarius). Biological Trace Element Research, 194, 390-400. https://doi.org/10.1007/ s12011-019-01788-2

6. ATSDR. 2005. Toxicological profile for zinc. Atlanta, Georgia: Agency for Toxic Substances and Disease Registry. Retrieved from https://www.atsdr. cdc.gov/toxprofiles/tp60.pdf

7. ATSDR. 2012. Toxicological profile for cadmium. Atlanta, Georgia: Agency for Toxic Substances and Disease Registry. Retrieved from https://www.atsdr. cdc.gov/toxprofiles/tp5.pdf

8. ATSDR. 2020. Toxicological profile for lead. Atlanta, Georgia: Agency for Toxic Substances and Disease Registry. https://doi. org/10.1201/9781420061888_ch106

9. Bąkowska M., Pilarczyk B., Tomza-Marciniak A., Udała J., Pilarczyk R. 2016. The bioaccumulation of lead in the organs of roe deer (Capreolus capreolus 
L.), red deer (Cervus elaphus L.), and wild boar (Sus scrofa L.) from Poland. Environmental Science and Pollution Research, 23(14), 14373-14382. https:// doi.org/10.1007/s11356-016-6605-5

10. Barath Kumar S., Padhi RK., Satpathy KK. 2019. Trace metal distribution in crab organs and human health risk assessment on consumption of crabs collected from coastal water of South East coast of India. Marine Pollution Bulletin, 141(February), 273-282. https://doi.org/10.1016/j.marpolbul.2019.02.022

11. Baydan E., Kanbur M., Arslanbaş E., Gönül Aydin F., Gürbüz,S., Yasin Tekeli M. 2017. Contaminants in animal products. In Livestock Science (pp. 131-152). https://doi.org/http://dx.doi. org/10.5772/67064

12. Bortey-Sam N., Nakayama SMM., Ikenaka Y., Akoto O., Baidoo E., Yohannes YB., ... Ishizuka M. 2015. Human health risks from metals and metalloid via consumption of food animals near gold mines in Tarkwa, Ghana: estimation of the daily intakes and target hazard quotients (THQs). Ecotoxicology and Enviromental Safety, 111(160-167). https://doi.org/ http://hdl.handle.net/2115/57933

13. CCME. 2007. Canadian soil quality guidelines for the protection of environmental and human health. Canadá: Canadian Council of Ministers of the Environment. https://doi. org/10.1177/004947559702700223

14. Chen H., Teng Y., Lu S., Wang Y., Wang J. 2015. Contamination features and health risk of soil heavy metals in China. Science of the Total Environment, 512-513, 143-153. https://doi.org/10.1016/j. scitotenv.2015.01.025

15. Chijioke NO., Uddin Khandaker M., Tikpangi KM., Bradley DA. 2020. Metal uptake in chicken giblets and human health implications. Journal of Food Composition and Analysis, 85, 103332. https://doi. org/10.1016/j.jfca.2019.103332

16. Cristofanelli S., Antonini M., Torres D., Polidori P., Renieri C. 2004. Meat and carcass quality from Peruvian llama (Lama glama) and alpaca (Lama pacos). Meat Science, 66(3), 589-593. https://doi. org/10.1016/S0309-1740(03)00174-8 [in spanish]

17. Cui Y. J., Zhu YG., Zhai RH., Chen DY., Huang YZ., Qiu Y., Liang JZ. 2004. Transfer of metals from soil to vegetables in an area near a smelterin Nanning, China. Environment International, 30(6), 785-791. https://doi.org/10.1016/j.envint.2004.01.003

18. Darwish WS., Chiba H., Elhelaly AE., Hui SP. 2019. Estimation of cadmium content in Egyptian foodstuffs: health risk assessment, biological responses of human HepG2 cells to food-relevant concentrations of cadmium, and protection trials using rosmarinic and ascorbic acids. Environmental Science and Pollution Research, 26(15), 15443-15457. https:// doi.org/10.1007/s11356-019-04852-5
19. DESCOSUR. 2017 Camelid meat. Arequipa, Peru: Center for Studies and Promotion of Southern Development. Retrieved from http://www.descosur. org.pe/wp-content/uploads/2017/11/Carne_camelidos.pdf [in spanish]

20. Djedjibegovic J., Marjanovic A., Tahirovic D., Caklovica K., Turalic A., Lugusic A., ... Caklovica F. 2020. Heavy metals in commercial fish and seafood products and risk assessment in adult population in Bosnia and Herzegovina. Scientific Reports, 10, 13238. https://doi.org/10.1038/ s41598-020-70205-9

21. El Bayomi RM., Darwish WS., Elshahat SSM., Hafez AE. 2018. Human health risk assessment of heavy metals and trace elements residues in poultry meat retailed in Sharkia Governorate, Egypt. Slovenian Veterinary Research, 55(Suppl 20), 211-219. https://doi.org/10.26873/SVR-647-2018

22. European Commission. 2006a. Commission Regulation (EC) No 118/2006 of 19 december 2006. Setting maximum levels for certain contaminants in foodstuffs. European Union. Retrieved from https:// eur-lex.europa.eu/legal-content/EN/TXT/PDF/?uri $=$ CELEX:32006R $1881 \&$ from $=\mathrm{EN}$

23. European Commission. 2006b. Directive 2002/32/ EC of the Europen parliament and of the council - on undesirable substances in animal feed. Official Journal of the European Committee. Retrieved from https://eur-lex.europa.eu/legal-content/EN/ TXT/PDF/?uri=CELEX:02002L0032-20131227 $\&$ from $=\mathrm{EN}$

24. FAO/WHO. 1982. Evaluation of certain food additives and contaminants. Food and Agriculture Organization of the United Nations and World Health Organization. WHO Technical Report Series 683. Geneva, Rome. Retrieved from https://apps.who. int/iris/handle/10665/41546

25. FAO/WHO. 2011. Evaluation of certain food additives and contaminants. Food and Agriculture Organization of the United Nations and World Health Organization. WHO Technical Report Series 960.

26. FAO/WHO. 2015. General standard for contaminants and toxins in food and feed (Codex Stan 193-1995). Food and Agricultural Organization of the United Nations and World Health Organization. Retrieved from http://www.fao.xn--orgcxs_193e_2015-cz6i

27. FAO. 1983. Compilation of legal limits for hazardous substances in fish and fishery products. Rome.

28. FAO. 2005. Development of products with alpaca meat. Rome, Italy: Food and Agricultural Organization of the United Nations. Retrieved from http:// www.fao.org/tempref/GI/Reserved/FTP_FaoRlc/ old/proyecto/163nze/documentos/productos/1.pdf

29. Felix O., John N., Ekene E. 2016. Assessment of lead $(\mathrm{Pb})$ residues in organs and muscles of slaughtered pigs at Nsukka and Environs in Enugu state, 
Nigeria. Journal of Advanced Veterinary and Animal Research, 3(4), 392-398. https://doi.org/10.5455/ javar.2016.c178

30. Gall JE., Boyd RS., Rajakaruna N. 2015. Transfer of heavy metals through terrestrial food webs: a review. Environmental Monitoring and Assessment, 187(4). https://doi.org/10.1007/s10661-015-4436-3

31. Hashemi M. 2018. Heavy metal concentrations in bovine tissues (muscle, liver and kidney) and their relationship with heavy metal contents in consumed feed. Ecotoxicology and Environmental Safety, 154, 263-267. https://doi.org/10.1016/j. ecoenv.2018.02.058

32. Hembrom S., Singh B., Kumar Gupta SK., Kumar Nema A. 2020. A comprehensive evaluation of heavy metal contamination in foodstuff and associated human health risk: A global perspective. In P. Singh, R. P. Singh, \& V. Srivastava (Eds.), Contemporary Environmental Issues and Challenges in Era of Climate Change (1 ed., pp. 33-63). Singapore: Springer Nature Singapore Pte Ltd. https://doi. org/10.1007/978-981-32-9595-7

33. Hermoso de Mendoza M., Hernández D., Soler F., López A., Fidalgo LE., Pérez M. 2011. Sex- and age-dependent accumulation of heavy metals $(\mathrm{Cd}$, $\mathrm{Pb}$ and $\mathrm{Zn}$ ) in liver, kidney and muscle of roe deer (Capreolus capreolus) from NW Spain. Journal of Environmental Science and Health - Part A, 46(2), 109-116. https://doi.org/10.1080/10934529.2011.5 32422

34. Hinojosa RA., Yzarra A., Ruiz JA., Castrejón M. 2019. Structural characterization of the alpaca production system (Vicugna pacos) in Huancavelica, Perú. Animal Science Archives, 68(261), 100-108. https://doi.org/10.21071/az.v68i261.3945 [in spanish]

35. Hu B., Jia X., Hu J., Xu D., Xia F., Li Y. 2017. Assessment of heavy metal pollution and health risks in the soil-plant-human system in the Yangtze river delta, China. International Journal of Environmental Research and Public Health, 14(9). https://doi. org/10.3390/ijerph14091042

36. Huanqui Pérez R. 2018. Determination of heavy metals in pastures, fiber, meat and viscera of alpacas in communities of the Ananea district - Puno. Universidad Nacional del Altiplano. [in spanish]

37. IARC. 2012. Arsenic, metals, fibres, and dusts. Lyon, France: International Agency for Research on Cancer. Retrieved from https://www.iarc.fr/

38. Islam MS., Hossain MB., Matin A., Islam Sarker MS. 2018. Assessment of heavy metal pollution, distribution and source apportionment in the sediment from Feni River estuary, Bangladesh. Chemosphere, 202, 25-32. https://doi.org/10.1016/j. chemosphere.2018.03.077

39. Jadia CD., Fulekar MH. 2009. Phytoremediation of heavy metals: Recent techniques. African Journal of Biotechnology, 8(6), 921-928. https://doi. org/10.5897/AJB2009.000-9152

40. Kabata-Pendias A. 2011. Trace elements in soils and plant (Fourth Ed.). London, New York: Taylor and Francis Group. Retrieved from http://www.taylorandfrancis.com

41. Khalafalla F. ., Abdel-Atty N. ., Abb-El-Wahab,M., Ali OI., Abo-Elsoud RB. 2015. Assessment of heavy metal residues in retail meat and offals. Journal of American Science, 11(5), 50-54.

42. Khan S., Cao Q., Zheng YM., Huang YZ., Zhu YG. 2008. Health risks of heavy metals in contaminated soils and food crops irrigated with wastewater in Beijing, China. Environmental Pollution, 152(3), 686692. https://doi.org/10.1016/j.envpol.2007.06.056

43. Khan Z I., Ugulu I., Umar S., Ahmad K., Mehm$\operatorname{ood}$ N., Ashfaq A., ... Sohail M. 2018. Potential toxic metal accumulation in soil, forage and blood plasma of buffaloes sampled from Jhang, Pakistan. Bulletin of Environmental Contamination and Toxicology, 101(2), 235-242. https://doi.org/10.1007/ s00128-018-2353-1

44. Kicińska A., Glichowska P., Mamak M. 2019. Micro- and macroelement contents in the liver of farm and wild animals and the health risks involved in liver consumption. Environmental Monitoring and Assessment, 191(3), 132. https://doi.org/10.1007/ s10661-019-7274-x

45. Korkmaz C., Ay Ö., Ersoysal Y., Köroğlu MA., Erdem C. 2019. Heavy metal levels in muscle tissues of some fish species caught from north-east Mediterranean: Evaluation of their effects on human health. Journal of Food Composition and Analysis, 81, 1-9. https://doi.org/10.1016/j.jfca.2019.04.005

46. Kortei NK., Heymann ME., Essuman EK., Kpodo FM., Akonor PT., Lokpo SY., ... Tettey C. 2020. Health risk assessment and levels of toxic metals in fishes (Oreochromis noliticus and Clarias anguillaris) from Ankobrah and Pra basins: Impact of illegal mining activities on food safety. Toxicology Reports, 7(August 2019), 360-369. https://doi. org/10.1016/j.toxrep.2020.02.011

47. Lehel J., Laczay P., Gyurcsó A., Jánoska F., Majoros S., Lányi K., Marosán M. 2015. Toxic heavy metals in the muscle of roe deer (Capreolus capreolus)-food toxicological significance. Environmental Science and Pollution Research, 23(5), 4465-4472. https://doi.org/10.1007/s11356-015-5658-1

48. Lü J., Jiao W., Qiu H., Chen B., Huang X., Kang B. 2018. Origin and spatial distribution of heavy metals and carcinogenic risk assessment in mining areas at You 'xi County southeast China. Geoderma, 310(January 2017), 99-106. https://doi. org/10.1016/j.geoderma.2017.09.016

49. MacLachlan DJ., Budd K., Connolly J., Derrick J., 
Penrose L., Tobin T. 2016. Arsenic, cadmium, cobalt, copper, lead, mercury, molybdenum, selenium and zinc concentrations in liver, kidney and muscle in Australian sheep. Journal of Food Composition and Analysis, 50, 97-107. https://doi.org/10.1016/j. jfca.2016.05.015

50. Mamani-Linares LW., Cayo F., Gallo C. 2014. Carcass characteristics, meat quality and chemical composition of llama meat: A review. Journal of Veterinary Research of Peru, 25(2), 123-150. https:// doi.org/10.1109/ITW.2013.6691279 [in spanish]

51. Miclean M., Cadar O., Levei EA., Roman R., Ozunu A., Levei L. 2019. Metal (Pb, Cu, Cd, and $\mathrm{Zn)}$ transfer along food chain and health risk assessment through raw milk consumption from freerange cows. International Journal of Environmental Research and Public Health, 16(21), 5-7. https://doi. org/10.3390/ijerph16214064

52. Ministery of Agricultural and Irrigation. (2019). Statistical Yearbook: Livestock and poultry production 2018. Lima, Perú: MINAGRI. Retrieved from http://siea.minagri.gob.pe/siea/?q=publicaciones/ anuario-de-produccion-pecuaria [in spanish]

53. Ministery of the Environment. (2017). Approve environmental quality standards for soil. D. S. $\mathrm{N}^{\circ}$ 011-2017-MINAM. Lima, Perú: El Peruano. Retrieved from http:/www.minam.gob.pe/wp-content/ uploads/2017/12/DS_011-2017-MINAM.pdf. [in spanish]

54. Ministry of Energy and Mines. (2000). Abandoned mines in the department of Huancavelica. Lima, Perú: Ministry of Energy and Mines. https://doi. org/10.1017/CBO9781107415324.004 [in spanish]

55. Miranda M., Alonso ML., Castillo C., Hernández J., Benedito JL. 2001. Cadmium levels in liver, kidney and meat in calves from Asturias (North Spain). European Food Research and Technology, 212(4), 426-430. https://doi.org/10.1007/s002170000266

56. National Academy of Sciences. 2005. Mineral tolerance of animals. Book (2nd rev. e). Washington DC: The National Academies Press. Retrieved from http://www.nap.edu/catalog.php?record_id=11309

57. Ogbomida ET., Nakayama SMM., Bortey-Sam N., Oroszlany B., Tongo I., Enuneku A. A., ... Ishizuka M. 2018. Accumulation patterns and risk assessment of metals and metalloid in muscle and offal of free-range chickens, cattle and goat in Benin City, Nigeria. Ecotoxicology and Environmental Safety, 151, 98-108. https://doi.org/10.1016/j. ecoenv.2017.12.069

58. Oyekunle JAO., Ore OT., Durodola SS., Oyinloye JA., Oyebode BA., Ajanaku OL. 2020. Heavy metal levels and changes in trimethylamine content of smoked fish and meat under different storage conditions. SN Applied Sciences, 2(6). https://doi. org/10.1007/s42452-020-2844-7
59. Pérez V., Maino M., Guzmán R., Vaquero A., Köbrich C., Pokniak J. 2000. Carcass characteristics of llamas (Lama glama) reared in Central Chile. Small Ruminant Research: The Journal of the International Goat Association, 37(1-2), 93-97. https://doi.org/ doi:10.1016/s0921-4488(99)00127-3

60. Pilarczyk B., Tomza-Marciniak A., Pilarczyk R., Udała J., Kruzhel B., Ligocki M. 2020. Content of essential and non-essential elements in wild animals from western Ukraine and the health risks associated with meat and liver consumption. Chemosphere, 244. https://doi.org/10.1016/j. chemosphere.2019.125506

61. Sabir S., Khan S., Hayat I. 2003. Effect of environmental pollution on quality of meat in district Bagh, Azad Kashmir. Pakistan Journal of Nutrition, 2(2), 98-101. https://doi.org/DOI: 10.3923/ pjn.2003.98.101

62. Shafiuddin Ahmed AS., Sultana S., Habib A., Ullah H., Musa N., Belal Hossain M., ... Shafiqul Islam Sarker M. 2019. Bioaccumulation of heavy metals in some commercially important fishes from a tropical river estuary suggests higher potential health risk in children than adults. PLoS ONE, 14(10), 1-21. https://doi.org/10.1371/journal.pone.0219336

63. Smith KM., Abrahams PW., Dagleish MP., Steigmajer J. 2009. The intake of lead and associated metals by sheep grazing mining-contaminated fl oodplain pastures in mid-Wales, UK : I . Soil ingestion, soil - metal partitioning and potential availability to pasture herbage and livest. Science of the Total Environment, The, 407(12), 3731-3739. https://doi. org/10.1016/j.scitotenv.2009.02.032

64. Sobhanardakani S. 2018. Human health risk assessment of $\mathrm{Cd}, \mathrm{Cu}, \mathrm{Pb}$ and $\mathrm{Zn}$ through consumption of raw and pasteurized cow' s milk. Iran J Public Health, 47(8), 1172-1180.

65. Stankovic S., Kalaba P., Stankovic A. 2014. Biota as toxic metal indicators. Environ Chem Lett, 12, 63-84. https://doi.org/DOI 10.1007/s10311-013-0430-6

66. Storelli A., Barone G., Dambrosio A., Garofalo R., Busco A., Storelli MM. 2020. Occurrence of trace metals in fish from South Italy: Assessment risk to consumer's health. Journal of Food Composition and Analysis, 90, 103487. https://doi.org/10.1016/j. jfca.2020.103487

67. Uauy R., Olivares M., Gonzalez M. 1998. Essentiality of copper in humans. The American Journal and Clinical Nutrition, 67, 952S-959S. https://doi. org/10.1111/j.1753-4887.1987.tb06081.x

68. USEPA. 1989. Risk assessment guidance for superfund. Volume I. Human health evaluation manual (Part A). Washington DC, USA: United States Environmental Protection Agency. Retrieved from https://rais.ornl.gov/documents/HHEMA.pdf

69. USEPA. 2001. Risk assessment guidance for 
superfund: Volume III - Part A, process for conducting probabilistic risk assessment. United States Environmental Protection Agency. Retrieved from http://www.epa.gov/sites/production/files/2015-09/ documents/rags3adt_complete.pdf

70. USEPA. 2007. Microwave assisted acid digestion of sediments, sludges, soils and oils, (United States Enviromental Protection Agency). Retrieved from https://www.epa.gov/sites/production/ files/2015-12/documents/3051a.pdf

71. USEPA IRIS. 2019. Integrated risk information system (IRIS). Regional screening levels (RSLs) - generic tables (November 2019). Washington DC, USA: United States Environmental Protection Agency. Retrieved from https://www.epa.gov/risk/ regional-screening-levels-rsls-generic-tables

72. Wang Z., Hong C., Xing Y., Wang K., Li Y., Feng L., Ma S. 2018. Spatial distribution and sources of heavy metals in natural pasture soil around coppermolybdenum mine in Northeast China. Ecotoxicology and Environmental Safety, 154(January), 329336. https://doi.org/10.1016/j.ecoenv.2018.02.048

73. Wilkinson JM., Hill J., Phillips CJC. 2003. The accumulation of potentially-toxic metals by grazing ruminants. Proceedings of the Nutrition Society, 62(2), 267-277. https://doi.org/10.1079/ pns2003209

74. Xiao R., Guo D., Ali A., Mi S., Liu T., Ren C., ... Zhang Z. 2019. Accumulation, ecological-health risks assessment, and source apportionment of heavy metals in paddy soils: A case study in Hanzhong, Shaanxi, China. Environmental Pollution, 248, 349357. https://doi.org/10.1016/j.envpol.2019.02.045

75. Yu G., Zheng W., Wang W., Dai F., Zhang Z., Yuan Y., Wang Q. 2017. Health risk assessment of chinese consumers to cadmium via dietary intake. Journal of Trace Elements in Medicine and Biology, 44, 137145. https://doi.org/10.1016/j.jtemb.2017.07.003

76. Zeinali T. 2019. Dietary intake of cadmium, chromium, copper, nickel, and lead through the consumption of meat, liver, and kidney and assessment of human health risk in Birjand, Southeast of Iran. Biological Trace Element Research, 191(2), 338-347. https://doi.org/https://doi.org/10.1007/ s12011-019-1637-6 Dietary

77. Zhang H., Mao Z., Huang K., Wang X., Cheng L., Zeng L., ... Jing T. 2019. Multiple exposure pathways and health risk assessment of heavy metal(loid)s for children living in fourth-tier cities in Hubei Province. Environment International, 129(May), 517-524. https://doi.org/10.1016/j. envint.2019.04.031

78. Zhang L., Mo Z., Qin J., Li Q., Wei Y., Ma S., ... Zou Y. 2015. Change of water sources reduces health risks from heavy metals via ingestion of water, soil and rice in a riverine area, South China. Science of the Total Environment, 530-531, 163-170. https:// doi.org/10.1016/j.scitotenv.2015.05.100 